\title{
Comment on "Exceptionally high heat flux needed to sustain the Northeast Greenland Ice Stream” by Smith-Johnsen et al. (2020)
}

\author{
Paul D. Bons ${ }^{1,2}$, Tamara de Riese ${ }^{2}$, Steven Franke ${ }^{3}$, Maria-Gema Llorens ${ }^{4}$, Till Sachau ${ }^{2}$, Nicolas Stoll ${ }^{3}$, \\ Ilka Weikusat $^{2,3}$, Julien Westhoff ${ }^{5}$, and Yu Zhang ${ }^{2}$ \\ ${ }^{1}$ School of Earth Science and Resources, China University of Geosciences, Beijing, China \\ ${ }^{2}$ Department of Geosciences, Eberhard Karls University Tübingen, Tübingen, Germany \\ ${ }^{3}$ Alfred Wegener Institute Helmholtz Centre for Polar and Marine Research, Bremerhaven, Germany \\ ${ }^{4}$ Geosciences Barcelona, CSIC, Barcelona, Spain \\ ${ }^{5}$ Physics of Ice, Climate and Earth, University of Copenhagen, Copenhagen, Denmark
}

Correspondence: Paul D. Bons (paul.bons@uni-tuebingen.de)

Received: 18 November 2020 - Discussion started: 17 December 2020

Revised: 18 March 2021 - Accepted: 6 April 2021 - Published: 17 May 2021

\begin{abstract}
Smith-Johnsen et al. (The Cryosphere, 14, 841854, https://doi.org/10.5194/tc-14-841-2020, 2020) model the effect of a potential hotspot on the Northeast Greenland Ice Stream (NEGIS). They argue that a heat flux of at least $970 \mathrm{~mW} \mathrm{~m}^{-2}$ is required to have initiated or to control NEGIS. Such an exceptionally high heat flux would be unique in the world and is incompatible with known geological processes that can raise the heat flux. Fast flow at NEGIS must thus be possible without the extraordinary melt rates invoked in Smith-Johnsen et al. (2020).
\end{abstract}

\section{Introduction}

The prominent Northeast Greenland Ice Stream (NEGIS) is an exceptionally large ice stream in the Greenland Ice sheet. It is over $500 \mathrm{~km}$ long, almost reaches the central ice divide and contributes significantly to overall ice drainage from the Greenland Ice sheet (Rignot and Mouginot, 2012; Aschwanden et al., 2016). What causes or drives this ice stream remains enigmatic. Several authors have suggested that NEGIS was initiated or is controlled by an elevated geothermal heat flux from the underlying bedrock (Fahnestock et al., 2001; Keisling et al., 2014; MacGregor et al., 2016). This hypothesis was investigated in the modelling study of Smith-Johnsen et al. (2020). They conclude that "a minimum heat flux value of $970 \mathrm{~mW} \mathrm{~m}^{-2}$ located close to the East Greenland Icecore Project (EGRIP) is required locally to reproduce the observed NEGIS velocities, giving basal melt rates consistent with previous estimates. The value cannot be attributed to geothermal heat flux alone and we suggest hydrothermal circulation as a potential explanation for the high local heat flux". It should be noted that this statement is preceded by the caveat "In our model experiment". The high minimum heat flux of $970 \mathrm{~mW} \mathrm{~m}^{-2}$ mainly derives from Fahnestock et al. (2001), who inferred it from their interpreted $0.1 \mathrm{~m} \mathrm{yr}^{-1}$ melt rate in the upstream area of NEGIS. MacGregor et al. (2016) obtained similar high melting rates in the upstream area of NEGIS, actually in a larger area than that assumed by Smith-Johnsen et al. (2020) in their modelling. However, Buchardt and Dahl-Jensen (2007) obtained a more than 10 times lower melt rate along the ridge between GRIP and NorthGRIP, which is on the margin of the high-melting rate area of MacGregor et al. (2016).

\section{Discussion}

An elevated geothermal heat flux is usually attributed to the trail of the Iceland plume (Rogozhina et al., 2016; Martos et al., 2018; Artemieva, 2019). For example, Rogozhina et al. (2016) suggest that the Iceland hotspot left a $400 \mathrm{~km}$ wide, roughly NW-SE-oriented swath of elevated geothermal heat flux across Greenland as the crust there was positioned above the hotspot 35-80 Myr ago. However, the elevated geothermal heat flux in the trail only reaches values of the order of $100 \mathrm{~mW} \mathrm{~m}^{-2}$ and is not expected to have local spikes. Vis- 
cous fingering of hot asthenosphere from the Iceland hotspot can potentially heat the overlying crust as far away as the North Sea according to Schoonman et al. (2017). However, temperatures drop off away from the central Iceland hotspot, especially underneath Greenland, as shown by, for example, the temperature at $80-150 \mathrm{~km}$ depth beneath Iceland and the adjacent Atlantic Ocean (Fig. 8 in Lebedev et al., 2017).

Fahnestock et al. (2001) base their inferred high heat flux on the depths of stratigraphic ice layers up to 9000 years in age, suggesting that the heat flux has at least been so high for the last few thousands of years. A steady-state $970 \mathrm{~mW} \mathrm{~m}^{-2}$ heat flux would imply a local geothermal gradient close to a staggering ca. $400^{\circ} \mathrm{C} \mathrm{km}^{-1}$, at which felsic rocks would melt at about $2 \mathrm{~km}$ depth. Although Fahnestock et al. (2001) suggest that the local bedrock topography is consistent with volcanism, there is no independent evidence for volcanism that is expected above such shallow melting.

Fahnestock et al. (2001) already note that $970 \mathrm{~mW} \mathrm{~m}^{-2}$ is many times the background median value of about $60 \mathrm{~mW} \mathrm{~m}^{-2}$ in continental crust, in which worldwide geothermal heat flux values rarely exceed $200 \mathrm{~mW} \mathrm{~m}^{-2}$ (Hofmeister and Criss, 2005; Davies, 2013). Recently, Rezvanbehbahani et al. (2017) used a machine learning technique that includes tectonic setting, regional geology and ice core measurements to predict a geothermal heat flux in a range of $20-150 \mathrm{~mW} \mathrm{~m}^{-2}$ across Greenland. These values are in line with geothermal heat flux values determined for Antarctica (Dziadek et al., 2017; Burton-Johnson et al., 2020a, b; Shen et al., 2020), with only local excursions above $200 \mathrm{~mW} \mathrm{~m}^{-2}$ in the tectonically active West Antarctic Rift System (Schroeder et al., 2014).

The geothermal heat flux map of Iceland (Jóhannesson et al., 2020) shows patches, several tens of kilometres in size, with $>200 \mathrm{~mW} \mathrm{~m}^{-2}$ and one smaller spot with $300-350 \mathrm{~mW} \mathrm{~m}^{-2}$, still far below $970 \mathrm{~mW} \mathrm{~m}^{-2}$. Similarly, Yellowstone, which is one of the most active continental hotspots, shows a geothermal heat flux just exceeding $150 \mathrm{~mW} \mathrm{~m}^{-2}$ (Blackwell and Richards, 2004). These two very active hotspots with active volcanic activity thus have geothermal heat fluxes well below $970 \mathrm{~mW} \mathrm{~m}^{-2}$. If geothermal heat flux values in the Iceland hotspot are $<350 \mathrm{~mW} \mathrm{~m}^{-2}$, it is highly unlikely that higher heat fluxes are encountered in its trail.

Active hotspots, such as Iceland and Yellowstone, are characterised by volcanic activity that implies the presence of magma chambers or shallow intrusions. Smith-Johnsen et al. (2020), recognising that $970 \mathrm{~mW} \mathrm{~m}^{-2}$ is unrealistically high for a geothermal heat flux, suggest several potential alternative processes that may enhance the high heat flux, such as shallow intrusions. This is in line with Stevens et al. (2016), who conclude, regarding melt, that "ice-age cycling could help it migrate upward to shallow depth or erupt, contributing to the high observed geothermal heat flux", but with the caveat "if melt occurs at depth". The conclusion is based on the vug-wave magma-transport model of Mor- gan and Holtzman (2005), which is similar to the mobilehydrofracture transport model of Bons (2001) and Bons et al. (2001). Magma transport in vug waves or mobile hydrofractures may be enhanced by ice-age cycling or tectonic events, but this will only have an effect if magma is present in the source region. The question remains if and why this would be the case underneath the upstream area of NEGIS. Furthermore, the same magma-transport mechanism also applies to igneous activity in hotspots such as Iceland. If the geothermal heat flux there is only raised locally to $<350 \mathrm{~mW} \mathrm{~m}^{-2}$, it is unlikely that it would be raised 3 times more in the Greenland crust, where there is no obvious evidence or reason for significant igneous activity.

Another potential cause for the high heat flux that is invoked by Smith-Johnsen et al. (2020) (and others, e.g. Artemieva, 2019) is hydrothermal fluid flow, which is the flux of hot fluids from deeper levels in the crust that typically leave mineral deposits (Oliver et al., 2006). An indication of the fluid flux required to achieve $0.1 \mathrm{~m} \mathrm{yr}^{-1}$ basal melting can be obtained by assuming that the melting is achieved by $100^{\circ} \mathrm{C}$ aqueous fluids that melt basal ice at $0^{\circ} \mathrm{C}$ while themselves cooling down to $0^{\circ} \mathrm{C}$. Using a heat capacity of $4.2 \mathrm{~kJ} \mathrm{~kg}^{-1} \mathrm{~K}^{-1}$ and a latent heat of $334 \mathrm{~kJ} \mathrm{~kg}^{-1}$ for melting ice, we obtain a required fluid flux of $\sim 2 \times 10^{-6} \mathrm{~kg} \mathrm{~m}^{-2} \mathrm{~s}^{-1}$ (or $\sim 0.07 \mathrm{~m}^{3} \mathrm{~m}^{-2} \mathrm{yr}^{-1}$ ). This is more than 3 orders of magnitude more than the $2-7 \times 10^{-10} \mathrm{~kg} \mathrm{~m}^{-2} \mathrm{~s}^{-1}$ expected for metamorphic fluid fluxes (Connolly and Thompson, 1989) that could potentially provide the hot fluids. Even the much lower estimated melting rate of $6.1 \mathrm{~mm} \mathrm{yr}^{-1}$ of Buchardt and Dahl-Jensen (2007) would require $>10$ times more mass of hot fluid than expected. Hydrothermal fluid flow can therefore not produce all the heat required for a significantly elevated basal melting rate.

Uranium enrichments are known in southern Greenland in the Gardar Province (e.g. Bartels et al., 2016), and their radiogenic heat production can add to the geothermal heat flux directly, and indirectly through enhanced hydrothermal fluid flow, as is the case in the uranium-rich Mount Painter Inlier in South Australia (Weisheit et al., 2013), where the geothermal heat flux is raised to about $120 \mathrm{~mW} \mathrm{~m}^{-2}$ (Sandiford et al., 1998). In the sediments above the world's largest known U deposit, Olympic Dam in South Australia, the geothermal heat flux is raised by only $43 \mathrm{~mW} \mathrm{~m}^{-2}$ from a background value of $73 \mathrm{~mW} \mathrm{~m}^{-2}$ (Houseman et al., 1989).

\section{Conclusions}

In summary, a heat flux of $970 \mathrm{~mW} \mathrm{~m}^{-2}$ is geologically unfeasible. Any heat flux above about $100-150 \mathrm{~mW} \mathrm{~m}^{-2}$ should be treated with caution in the absence of other evidence, such as volcanic or tectonic activity. Most other studies actually do propose much more moderate and realistic geothermal heat flux values below the Greenland Ice sheet (e.g. Buchardt and Dahl-Jensen, 2007; Rogozhina et al., 
2016; Rezvanbehbahani et al., 2017; Artemieva, 2019). The original $970 \mathrm{~mW} \mathrm{~m}^{-2}$ stems from Fahnestock et al. (2001), who derive this value from variations in radar stratigraphy elevation, which they assume to have been caused by basal melting (up to $0.1 \mathrm{~m} \mathrm{yr}^{-1}$ ). The improbable heat flux value they derive means that such elevation variations cannot be solely due to basal melting, and we need to consider other causes, such as flow heterogeneities in space or time (e.g. due to folding; Bons et al., 2016), as well as the underlying assumptions in determining basal melting.

Even though the extraordinary heat flux invoked in SmithJohnsen et al. (2020) cannot exist at NEGIS, their model results are definitively useful. They indicate that some other weakness exists in the NEGIS system that enables the fast flow, most likely with a supporting role of geologically plausible heat fluxes. The studies by both Fahnestock et al. (2001) and Smith-Johnsen et al. (2020) thus highlight the exciting challenge still ahead to truly understand ice streams such as NEGIS and ice sheet dynamics in general.

Data availability. No data sets were used in this article.

Author contributions. PDB provided the initial idea and concept of the paper, which was discussed and written jointly by all authors.

Competing interests. The authors declare that they have no conflict of interest.

Acknowledgements. Maria-Gema Llorens is supported by a Juan de la Cierva-Incorporación fellowship, funded by the Spanish Ministry of Science, Innovation and Universities, Nicolas Stoll and Ilka Weikusat by the Helmholtz Junior Research group "The effect of deformation mechanisms for ice sheet dynamics", Yu Zhang by the $\mathrm{PhD}$ programme of the China Scholarship Council (CSC), Julien Westhoff by the Villum Investigator Project IceFlow, and Steven Franke by the AWI-Strategy fund. We thank Nanna Bjørnholt Karlsson for carefully checking the original submission and Jörg Ebbing and Nicholas Holschuh for their helpful reviews.

Financial support. This research has been supported by the Spanish Ministry of Science, Innovation and Universities (Juan de la Cierva-Incorporación fellowship grant no. IJC2018-036826-I), the China Scholarship Council, Chinese Government Scholarship (grant no. 202006010063), the Alfred Wegener Institute Helmholtz Centre for Polar and Marine Research (grant no. VH-NG-802), and the Velux Foundations (Villum Investigator Project no. 16572).

Review statement. This paper was edited by Nanna Bjørnholt Karlsson and reviewed by Jörg Ebbing and Nicholas Holschuh.

\section{References}

Artemieva, I. M.: Lithosphere thermal thickness and geothermal heat flux in Greenland from a new thermal isostasy method, Earth-Scie. Rev., 188, 469-481, https://doi.org/10.1016/j.earscirev.2018.10.015, 2019.

Aschwanden, A., Fahnestock, M., and Truffer, M.: Complex Greenland outlet glacier flow captured, Nat. Com., 7, 10524, https://doi.org/10.1038/ncomms10524, 2016.

Bartels, A., Nilsson, M. K. M., Klausen, M. B., and Söderlund, U.: Mesoproterozoic dykes in the Timmiarmiit area, Southeast Greenland: evidence for a continuous Gardar dyke swarm across Greenland's North Atlantic Craton, GFF, 138, 255-275, https://doi.org/10.1080/11035897.2015.1125386, 2016.

Blackwell, D. D. and Richards, M.: Geothermal Map of North America, AAPG Map, scale 1:6500 000, 2004.

Bons, P. D.: The formation of large quartz veins by rapid ascent of fluids in mobile hydrofractures, Tectonophys., 336, 1-17, https://doi.org/10.1016/S0040-1951(01)00090-7, 2001.

Bons, P. D., Dougherty-Page, J., and Elburg, M. A.: Stepwise accumulation and ascent of magmas, J. Metamorphic Geol., 19, 627633, https://doi.org/10.1046/j.0263-4929.2001.00334.x, 2001.

Bons, P. D., Jansen, D., Mundel, F., Bauer, C. C., Binder, T., Eisen, O., Jessell, M. W., Llorens, M.-G., Steinbach, F., Steinhage, D., and Weikusat, I.: Converging flow and anisotropy cause large-scale folding in Greenland ice sheet, Nat. Com., 7, 11427, https://doi.org/10.1038/ncomms11427, 2016.

Buchardt, S. L. and Dahl-Jensen, D.: Estimating the basal melt rate at NorthGRIP using a Monte Carlo technique, Ann. Glaciol., 45, 137-142, https://doi.org/10.3189/172756407782282435, 2017.

Burton-Johnson, A., Dziadek, R., Martin, C., Halpin, J. A., Whitehouse, P. L., Ebbing, J., Martos, Y., Martin, A., Schroeder, D., Shen, W., Ritz, C., Goodge, J., Van Liefferinge, B., Pattyn, F., Reading, A., Ferraccioli, F., and The SERCE Geothermal Heat Flow Sub-Group: SARCSERCE White Paper on Antarctic Geothermal Heat Flow: Future research directions, available at: https://scar.org/ scar-library/search/science-4/research-programmes/serce/ 5454-scar-serce-white-paper-on-antarctic-geothermal-heat-flow/ (last access: 10 March 2021), 2020a.

Burton-Johnson, A., Dziadek, R., and Martin, C.: Review article: Geothermal heat flow in Antarctica: current and future directions, The Cryosphere, 14, 3843-3873, https://doi.org/10.5194/tc-143843-2020, 2020b.

Connolly, J. A. D. and Thompson, A. B.: Fluid and enthalpy production during regional metamorphism, Contrib. Mineral. Petrol., 102, 347-366, 1989.

Davies, J. H.: Global map of solid Earth surface heat flow, Geochem. Geophy. Geosy., 14, 4608-4622, https://doi.org/10.1002/ggge.20271, 2013.

Dziadek, R., Gohl, K., Diehl, A., and Kaul, N.: Geothermal heat flux in the Amundsen Sea sector of West Antarctica: New insights from temperature measurements, depth to the bottom of the magnetic source estimation, and thermal modeling, Geochem. Geophy. Geosy., 18, 2657-2672, https://doi.org/10.1002/2016GC006755, 2017.

Fahnestock, M., Abdalati, W., Joughin, I., Brozena, J., and Gogineni, P.: High Geothermal Heat Flow, Basal Melt, and the Origin of Rapid Ice Flow in Central Greenland, Science, 294, 23382342, https://doi.org/10.1126/science.1065370, 2001. 
Hofmeister, A. M. and Criss, R. E.: Earth's heat flux revised and linked to chemistry, Tectonophys., 395, 159-177, https://doi.org/10.1016/j.tecto.2004.09.006, 2005.

Houseman, G. A., Cull, J. P., Muir, P. M., and Paterson, H. L.: Geothermal signatures and uranium ore deposits on the Stuart Shelf of South Australia, Geophysics, 54, 158-170, https://doi.org/10.1190/1.1442640, 1989.

Jóhannesson, T., Pálmason, B., Hjartarson, Á., Jarosch, A. H., Magnússon, E., Belart, J. M. C., and Gudmundsson, M. T.: Nonsurface mass balance of glaciers in Iceland, J. Glaciol., 66, 1-13, https://doi.org/10.1017/jog.2020.37, 2020.

Keisling, B., Christianson, K., Alley, R. B., Peters, L. E., Christian, J. E. M., Anandakrishnan, S., Riverman, K. L., Muto, A., and Jacobel, R. W.: Basal conditions and ice dynamics inferred from radar-derived internal stratigraphy of the northeast Greenland ice stream, Ann. Glaciol., 55, 127-137, https://doi.org/10.3189/2014AoG67A090, 2014.

Lebedev, S., Schaeffer, A. J., Fullea, J., and Pease, V.: Seismic tomography of the Arctic region: inferences for the thermal structure and evolution of the lithosphere, Geol. Soc., London, Spec. Pubs., 460, 419-440, https://doi.org/10.1144/SP460.10, 2017.

Macgregor, J., Fahnestock, M., Catania, G., Aschwanden, A., Clow, G., Colgan, W., Gogineni, S., Morlighem, M., Nowicki, S., Paden, J., Price, S., and Seroussi, H.: A synthesis of the basal thermal state of the Greenland Ice Sheet, J. Geophys. Res.-Earth Surf., 121, 1328-1350, https://doi.org/10.1002/2015JF003803, 2016.

Martos, Y. M., Jordan, T. A., Catalán, M., Jordan, T. M., Bamber, J. L., and Vaughan, D. G.: Geothermal heat flux reveals the Iceland hotspot track underneath Greenland, Geophys. Res. Lett., 45, 8214-8222, https://doi.org/10.1029/2018GL078289, 2018.

Morgan, P. J. and Holtzman, B. K.: Vug waves: A mechanism for coupled rock deformation and fluid migration, Geochem. Geophy. Geosy., 6, Q08002, https://doi.org/10.1029/2004GC000818, 2005.

Oliver, N. H. S., McLellan, J. G., Hobbs, B. E., Cleverley, J. S., Ord, A., and Feltrin, L.: Numerical models of extensional deformation, heat transfer, and fluid flow across basement cover interfaces during basin-related mineralization, Econ. Geol., 101, 1-31, https://doi.org/10.2113/gsecongeo.101.1.1, 2006.

Rezvanbehbahani, S., Stearns, L. A., Kadivar, A., Walker, J. D., and van der Veen, C. J.: Predicting the geothermal heat flux in Greenland: A machine learning approach, Geophys. Res. Lett., 44, 12271-12279, https://doi.org/10.1002/2017GL075661, 2017.
Rignot, E. and Mouginot, J.: Ice flow in Greenland for the International Polar Year 2008-2009, Geophys. Res. Lett., 39, 1-7, https://doi.org/10.1029/2012GL051634, 2012.

Rogozhina, I., Petrunin, A. G., Vaughan, A. P. M., Steinberger, B., Johnson, J. V., Kaban, M. K., Calov, R., Rickers, F., Thomas, M., and Koulakov, I.: Melting at the base of the Greenland ice sheet explained by Iceland hotspot history, Nat. Geosci., 9, 366-369, https://doi.org/10.1038/ngeo2689, 2016.

Sandiford, M., Hand, M., and McLaren, S.: High geothermal gradient metamorphism during thermal subsidence, Earth Planet. Sci. Lett., 163, 149-165, https://doi.org/10.1016/S0012821X(98)00183-6, 1998.

Schoonman, C. M., White, N. J., and Pritchard, D.: Radial viscous fingering of hot asthenosphere within the Icelandic plume beneath the North Atlantic Ocean, Earth Planet. Sci. Lett., 468, 5161, https://doi.org/10.1016/j.epsl.2017.03.036, 2017

Schroeder, D. M., Blankenship, D. D., Young, D. A., and Quartini, E.: Evidence for elevated and spatially variable geothermal flux beneath the West Antarctic Ice Sheet, P. Natl. Acad. Sci. USA, 111, 9070-9072, https://doi.org/10.1073/pnas.1405184111, 2014.

Shen, W., Wiens, D., Lloyd, A., and Nyblade, A.: A geothermal heat flux map of Antarctica empirically constrained by seismic structure, Geophys. Res. Lett., 47, e2020GL086955, https://doi.org/10.1029/2020GL086955, 2020.

Smith-Johnsen, S., de Fleurian, B., Schlegel, N., Seroussi, H., and Nisancioglu, K.: Exceptionally high heat flux needed to sustain the Northeast Greenland Ice Stream, The Cryosphere, 14, 841854, https://doi.org/10.5194/tc-14-841-2020, 2020.

Stevens, N. T., Parizek, B. R., and Alley, R. B.: Enhancement of volcanism and geothermal heat flux by ice-age cycling: A stress modeling study of Greenland, J. Geophys. Res.-Earth Surf., 121, 1456-1471, https://doi.org/10.1002/2016JF003855, 2016.

Weisheit, A., Bons, P. D., Danisik, M., and Elburg, M. A.: Crustalscale folding: Palaeozoic deformation of the Mt. Painter Inlier, South Australia, Geol. Soc., London, Spec. Pubs., 394, 53-77, https://doi.org/10.1144/SP394.9, 2013. 